\title{
Blood Biochemical Profile of Early Weaned Kids Fed on Different Sources of Vegetable Protein
}

\author{
Namita Bezbaruah ${ }^{1}$, Mridushmita Sonowal ${ }^{2 *}$, Pranjal Borah ${ }^{3}$ and Santanu Tamuly ${ }^{1}$ \\ ${ }^{1}$ Department of Animal Nutrition, College of Veterinary Science, Assam Agricultural \\ University, Khanapara, Guwahati-781022, Assam, India \\ ${ }^{2}$ Livestock Research Station, AAU, Mandira, Kamrup, Assam, India \\ ${ }^{3}$ Goat Research Station, AAU, Burnihat, Kamrup, Assam, India \\ *Corresponding author
}

\section{A B S T R A C T}

\section{Keywords}

Ground nut cake, Soybean meal,

Sesame oil cake,

Beetal and Assam

Hill Goat

Article Info

Accepted:

17 June 2020

Available Online:

10 July 2020
Eighteen crossbred (Beetal x Assam Hill Goat) kids of 1 month of age were selected on the basis of their body weight and divided into three experimental groups of six animals each (group $\mathrm{T}_{1}, \mathrm{~T}_{2}$ and $\mathrm{T}_{3}$ ) and were offered creep diets containing three different sources of vegetable protein viz, soybean meal, ground nut cake, and sesame oil cake respectively for two months. Blood sample was collected on day 0 and 60 of experiment from jugular vein to analyse different blood biochemical profile. Significantly lower $(\mathrm{P}<0.01)$ blood glucose level was observed in $\mathrm{T}_{2}$ groups fed with ground nut cake protein as compared to soybean meal $\left(\mathrm{T}_{1}\right)$ and sesame oil cake meal $\left(\mathrm{T}_{3}\right)$. No significant difference was observed in total serum protein, albumin and globulin level in all the experimental groups.

\section{Introduction}

India is an important goat producing country which houses 148.88 Million $\left(20^{\text {th }}\right.$ Livestock Census, 2019) goat showing an increasing trend of 10.10 per cent over the previous $19^{\mathrm{th}}$ census. Raising young goat kids is a challenging job in terms of providing proper nutrition along with other managemental care. Early weaning followed by proper feeding management of young kids done by colostrum feeding, early introduction of concentrate feeds, milk replacer, creep or kid starter feeds or good quality roughages.
Protein and energy are the two major components of livestock feeds. Different protein sources have varying affects on ruminant performance and their serum biochemistry (Jorgensen et al., 1984). Different vegetable protein sources are used to formulate rations which differ in amino acid profile resulting in various responses of the animals. The varied responses may be due to changes in rumen ecology and their different amino acid profile (Hall and Huntington, 2008). Hence, keeping in view to these facts an experiment was designed to 
investigate the blood biochemical profile of early weaned kids fed on different sources of vegetable protein viz. Soybean meal, sesame oil cake and mustard oil cake.

\section{Materials and Methods}

Eighteen crossbred (Beetal x Assam Hill Goat) kids of 1 month of age were selected on the basis of their body weight. The kids were divided into three experimental groups of six animals $\left(\mathrm{T}_{1}, \mathrm{~T}_{2}\right.$ and $\left.\mathrm{T}_{3}\right)$ which were offered creep diets with 18 per cent $\mathrm{CP}$ and 77 per cent TDN (ICAR, 2013) individually for two months i.e till the $90^{\text {th }}$ days of age of the kids.

Blood sample was collected from the experimental kids on day 0 and 60 of experiment from jugular vein following the standard procedure to analyse different blood biochemicals as per standard methods. Data were analysed by using IBM-SPSS version 20.

\section{Results and Discussion}

The mean blood glucose level at the end of the experimental period was $143.93 \pm 11.32$, $92.04 \pm 4.63$ and $132.26 \pm 4.70 \mathrm{mg} / \mathrm{dl}$ in $\mathrm{T}_{1}, \mathrm{~T}_{2}$ and $\mathrm{T}_{3}$ group respectively. Significantly lower $(\mathrm{P}<0.01)$ blood glucose level was observed in
$\mathrm{T}_{2}$ groups fed with ground nut cake protein as compared to soybean meal $\left(\mathrm{T}_{1}\right)$ and sesame oil cake meal $\left(\mathrm{T}_{3}\right)$. Ground nut cake consumption showed significant reduction in blood glucose level due to the presence of mono-unsaturated fatty acids (Ramesh et al. 2006). Mono-unsaturated fatty acids (MUFA) stimulate secretion of the Glucagon-like peptide-1 (GLP-1) thus reduces the level of circulating glucose (Rocca et al., 2001). Similar findings was also reported by Rasmussen et al. (1993) where they observed reduction in peak plasma glucose concentration with the consumption of monounsaturated fatty acid rich diet. Pannampalam et al. (2005) reported significant increase in plasma glucose level in crossbred lambs at $30^{\text {th }}$ and $53^{\text {rd }}$ days of experimental period of feeding canola meal, soybean meal and fish meal supplemented diet. Increase in glucose concentration may be due to more bypass protein and increased availability of glucogenic amino acids for glucose synthesis (Sane et al. 2007). However, in contrast to the present findings Rusche et al. (1993) reported decreased plasma glucose concentrations in goats fed with crude protein source having high escape protein. They observed higher blood glucose level when supplemented with lucerne chaff and cotton seed meal.

Table.1 The composition and nutritive value of the experimental diets

\begin{tabular}{|l|c|c|c|}
\hline Ingredients & $\mathbf{T}_{\mathbf{1}}(\boldsymbol{\%})$ & $\mathbf{T}_{\mathbf{2}}(\boldsymbol{\%})$ & $\mathbf{T}_{\mathbf{3}}(\boldsymbol{\%})$ \\
\hline Maize & 50.85 & 53.56 & 50.43 \\
\hline Wheat bran & 13 & 13 & 13 \\
\hline SBM & 26.15 & - & - \\
\hline GNC & - & 23.44 & - \\
\hline SOC & - & - & 27.57 \\
\hline Molasses & 2 & 2 & 1 \\
\hline Fish meal & 5 & 5 & 5 \\
\hline Mineral mixture & 2 & 2 & 2 \\
\hline Common salt & 1 & 1 & 1 \\
\hline DCP (\%) & 18.29 & 18.29 & 18.29 \\
\hline TDN (\%) & 77.38 & 75.69 & 77.26 \\
\hline
\end{tabular}


Table.2 Blood biochemical profile of early weaned kids fed on different sources of vegetable protein

\begin{tabular}{|l|c|c|c|c|c|c|}
\hline \multirow{2}{*}{ Constituents } & \multicolumn{3}{|c|}{ Dietary treatment group } \\
\cline { 2 - 8 } & \multicolumn{2}{|c|}{$\mathbf{T}_{\mathbf{1}}$} & \multicolumn{2}{c|}{$\mathbf{T}_{\mathbf{2}}$} & \multicolumn{2}{c|}{$\mathbf{T}_{\mathbf{3}}$} \\
\hline Glucose (mg/dl) & $131.63 \pm 5.79$ & $143.93 \pm 11.32$ & $125.85 \pm 9.24$ & $92.04 \pm 4.63^{* *}$ & $122.30 \pm 8.83$ & $132.26 \pm 4.70$ \\
\hline Total protein (g/dl) & $11.92 \pm 0.61$ & $16.43 \pm 1.85$ & $8.04 \pm 0.36$ & $12.55 \pm 0.94$ & $11.12 \pm 0.46$ & $15.77 \pm 1.44$ \\
\hline Blood albumin (g/dl) & $2.95 \pm 0.18$ & $3.03 \pm 0.44$ & $2.47 \pm 0.20$ & $2.92 \pm 0.18$ & $2.88 \pm 0.11$ & $3.44 \pm 0.22$ \\
\hline Blood globulin (g/dl) & $8.98 \pm 0.65$ & $13.41 \pm 1.51$ & $5.57 \pm 0.34$ & $9.63 \pm 1.08$ & $8.24 \pm 0.14$ & $12.33 \pm 1.45$ \\
\hline $\begin{array}{l}\text { Albumin/Globulin } \\
\text { ratio }\end{array}$ & $0.34 \pm 0.04$ & $0.23 \pm 0.03$ & $0.46 \pm 0.05$ & $0.33 \pm 0.05$ & $0.35 \pm 0.02$ & $0.31 \pm 0.05$ \\
\hline
\end{tabular}

**P $<0.01$ - Highly significant

Fig Graphical representation of blood biochemical profile in kids

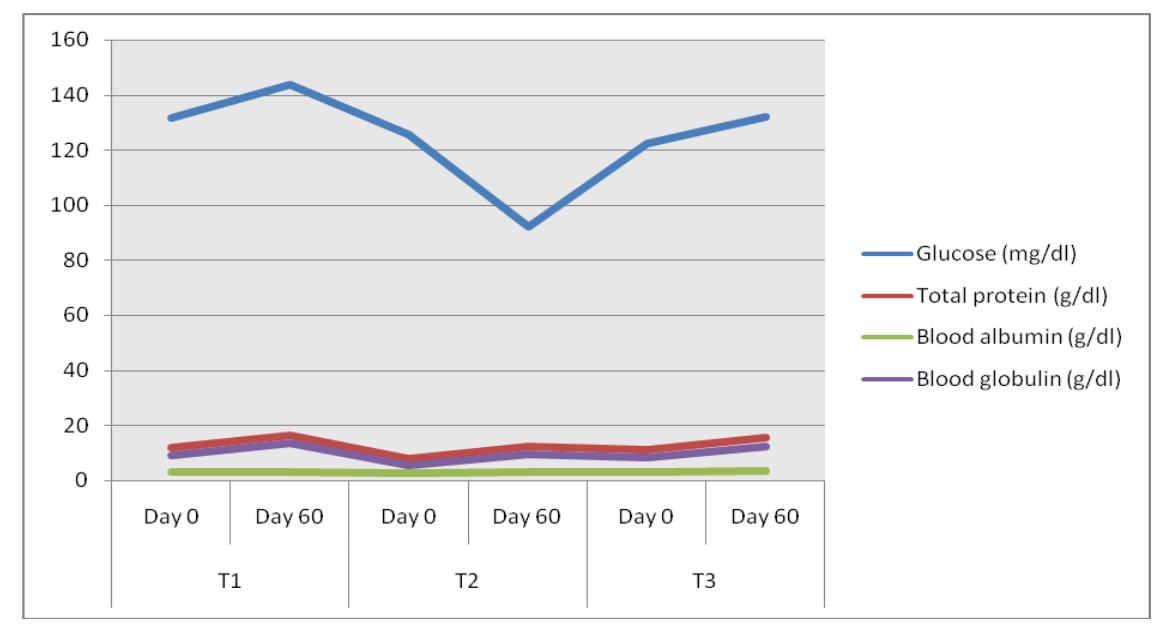

The total serum protein, albumin and globulin level increased numerically in all the experimental groups (Table 2) at the end of the experiment from the initial values, however, the increase was statistically nonsignificant. The minor variations in serum protein level in different groups may be due to varied level of dietary nitrogen intake. Virk et al. (1991) reported that serum protein levels were $6.12,6.21,6.41$ and $6.37 \mathrm{~g}$ per cent when CP of GNC was replaced by Faba bean seed at four different levels in crossbred goats. Gregoire et al. (1996) supplemented Angora female kids with soybean, soybean and protected methionine (Mepron), herring meal or corn gluten meal and could not find any significant differences in metabolic parameters, growth and mohair production.

The study indicated that soybean meal and sesame oil cake were better feed ingredients in terms of maintaining blood glucose level besides maintaining the normal serum protein level.

\section{References}

Gregoire, R.J., Fahmy, M.H., Boucher, M., Treblay, A. and Mercier, J. 1996. Effect of four protein supplements on growth, feed conversion, mohair production, fibre characteristics and blood 
parameters of Angora goats. Small Ruminant Research. 19(2): 121-130.

Hall, M.B., and Huntington, G.B. 2008. Nutrient synchrony: Sound in theory, elusive in practice. International Journal of Animal Science. 82,32373244.

ICAR (2013). Nutrient Requirement for sheep, Goat and Rabbit. Indian Council of Agricultural Research. New Delhi.

Jorgensen, H., Sauer, W.C., and Thacker, P.A. 1984. Amino acid availability in soybean meal, sunflower meal, fish meal and meat and bone meal fed to growing pigs. International Journal of Animal Science. 58, 926-934.

Ponnampalam, E.N., Warner, R.D., Suster, D. and Dunshea, F.R. 2005. Breed and nutrition influence the responses to homeostatic signals in lambs. Proceedings of the Nutrition Society of Australia. 29 (Suppl.), S7.

Ramesh, B., Saravanan, R., and Pugalendi,
K.V. 2006. Effect of dietary substitution of groundnut oil on blood glucose, lipid profile and redox status in Streptozotocin - diabetic rats.Yale Journal of Biology and Medicine. 79, 9-17.

Rasmussen, O.W., Thomsen, C., Hansen, K.W., Vesterlund, M., Winter, E., and Hermansen, K. 1993. Effects on blood pressure, glucose, and lipid levels of a high-monounsaturated fat diet compared with a high-carbohydrate diet in NIDDM subjects. Diabetes Care. 16, 1565-71.

Rocca, A.S., LaGreca, J., Kalitsky, J. and Brubaker, P.L. 2001. Monounsaturated fatty acid diets improve glycemic tolerance through increased secretion of Glucagon-like peptide-1. Endocrinology. 142 (3): 1148-55. Doi: 10.1210/endo.142.3.8034.

\section{How to cite this article:}

Namita Bezbaruah, Mridushmita Sonowal, Pranjal Borah and Santanu Tamuly. 2020. Blood Biochemical Profile of Early Weaned Kids Fed on Different Sources of Vegetable Protein. Int.J.Curr.Microbiol.App.Sci. 9(07): 1822-1825. doi: https://doi.org/10.20546/ijcmas.2020.907.209 